UNITED STATES

DEPARTMENT OF THE INTERIOR

GEOLOGICAL SURVEY

WATER RESOURCES OIVISION

\title{
FLOOD OF JUNE 7, 1967 , \\ IN THE WAPSINONOC CREEK BASIN, IOWA
}

\author{
By \\ Harlan H. Schwob \\ Hydroulic Engineer \\ U. S. Geological Survey
}

Prepared in cooperation with the IOWA STATE HIGHWAY COMMISSION

\author{
Open-file Report \\ $68-6$ \\ lowa City, lowa \\ January 1968
}




\title{
FLOOD OF JUNE 7, 1967, \\ IN THE WAPSINONOC CREEK BASIN, IOWA
}

\author{
By \\ Horlan H. Schwob \\ Hydraulic Engineer \\ U. S. Geological Survey \\ Prepared in cooperation with the \\ IOWA STATE HIGHWAY COMMISSION \\ Open-file Report
}

lowa City, lowa

Januory 1968 


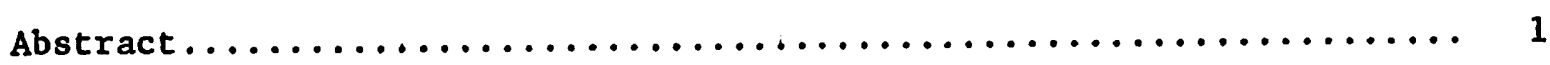

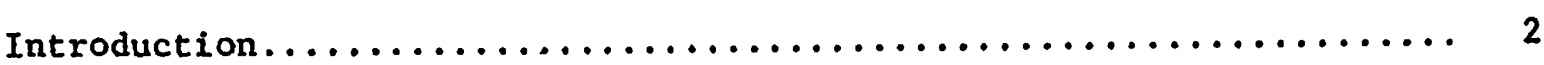

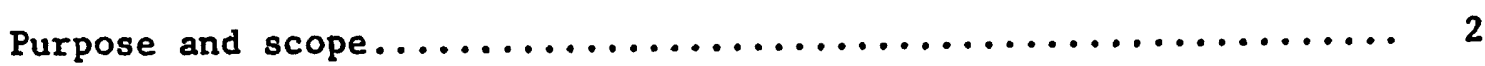

Acknowledgments .................................. 3

Topography of basin $\ldots \ldots \ldots \ldots \ldots \ldots \ldots \ldots \ldots \ldots \ldots \ldots \ldots \ldots \ldots$

Basic data.................................... 5

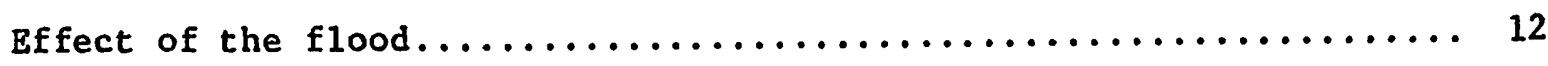

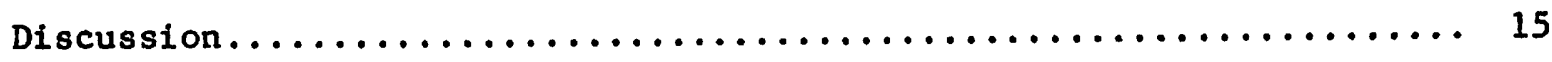

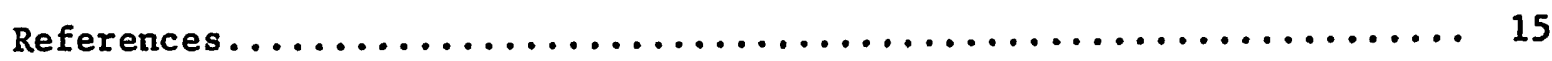

Appexdix....................................... 16

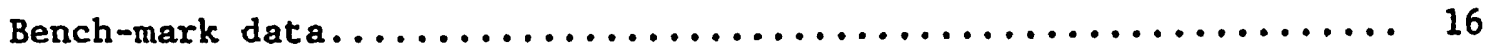

\section{ILLUSTRATIONS}

Figure 1. Map of Wapsinonoc Creek basin showing indirect discharge measurement sites and isohyetal data......... 4

2. Profiles of June 7, 1967, high water and streambed in Wapsinonoc Creek basin.

3. Peak discharge of Wapsinonoc Creek and selected streams .

\section{TABLES}

Table 1. Data pertaining to flood of June 7, 1967, in

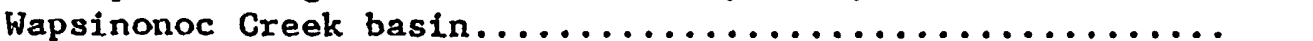


FLOOD OF JUNE 7, 1967, IN THE WAPSINONOC CREEK BASIN, IOWA

by

Harlan H. Schwob

\begin{abstract}
An outstanding flood occurred in the Wapsinonoc Creek basin in eastcentral Iowa on June 7,1967 . The flood was the result of rainfall totaling from 4 to 13 inches in about 14 hours on the night of June 6 and the morning of June 7. The storm was nearly centered over the 180-square mile basin. The resulting peak discharges ranged from about 1.9 to about 4.3 times the 50-year recurrence interval flood. A peak discharge of 27,400 cubic feet per second was measured from 161 square miles of the basin. This and other peak discharges for drainage areas larger than 40 square miles were among the greatest recorded in the last 50 years in eastern Iowa. Flood damage was light because the basin is used primarily for agriculture and the crops were in their early growth stage. There was no loss of human Iife attributed to the flood.
\end{abstract}




\section{INTRODUCTION}

An outstanding hydrologic event occurred on the night of June 6,7 , 1967, in east-central Iowa. A storm over the Wapsinonoc Creek basin dropped from 4 to 13 inches of rain in a period of about 14 hours. Because the storm was nearly centered over the 180-square mile basin and because of the amount of rain the resulting floods were outstanding. Damages, however, were light because the basin is primarily agricultural and the crops were in their early stages of growth and because the town areas were small and largely located outside the flooded area.

\section{Purpose and Scope}

The purpose of this report is to present flood data for the Wapsinonoc Creek basin. Other data that aid this purpose are also included. The data presented are an isohyetal map showing total rainfall for the storm, elevations of the flood crest and of the streambed, peak flood discharges, and the discharge for the 50-year recurrence interval flood. These data are tabulated for many points along the short main stem and two of the major tributaries. A graphical comparison is shown for the measured peak discharges in the basin and peak discharges that have occurred on nearby streams in the past 50 years.

No official rain gages or streamflow gages are located in the basin. This fact limits the scope of the report by precluding rainfall distribution and volumetric streamflow studies. Precipitation gages located outside the basin were not in the area of extreme rainfall. 


\section{Acknowledgments}

The collection of the flood data and preparation of the report result from a cooperative program between the Iowa State Highway Commission, through the Iowa Highway Research Board, and the U.S. Geological Survey. The isohyetal map (fig. 1), that forms an important part of this report was prepared from data provided by the Iowa Natural Resources Council, based on a "bucket" survey made of the area. This contribution is gratefully acknowledged.

TOPOGRAPHY OF THE BASIN

Wapsinonoc Creek is a right-bank tributary of the Cedar River in the Iowa River basin. The mouth of the creek is 44.2 miles upstream from the mouth of the Iowa River and 15.2 miles upstream from the junction of the Cedar and Iowa Rivers. The basin is nearly elliptical with the long axis approximately oriented in a north-south direction. The stream pattern consists of a short main stem with several major and many minor tributaries. The major tributaries are Big Slough, West Branch Wapsinonoc Creek, East Branch Wapsinonoc Creek, and Middle Branch Wapsinonoc Creek. Figure 1 shows the location of the basin with respect to state and county lines.

The town of West Liberty (population 2,042 in 1960) lies about two miles southeast of the center of the basin. The other towns or unincorporated communities are West Branch (population, 1,053) in the northwest part of the basin; Springdale (unincorporated) in the northeast part of the basin; Downey (unincorporated) in the west-central part of the basin; and Nichols (population, 329) in the southwest part of the basin. 


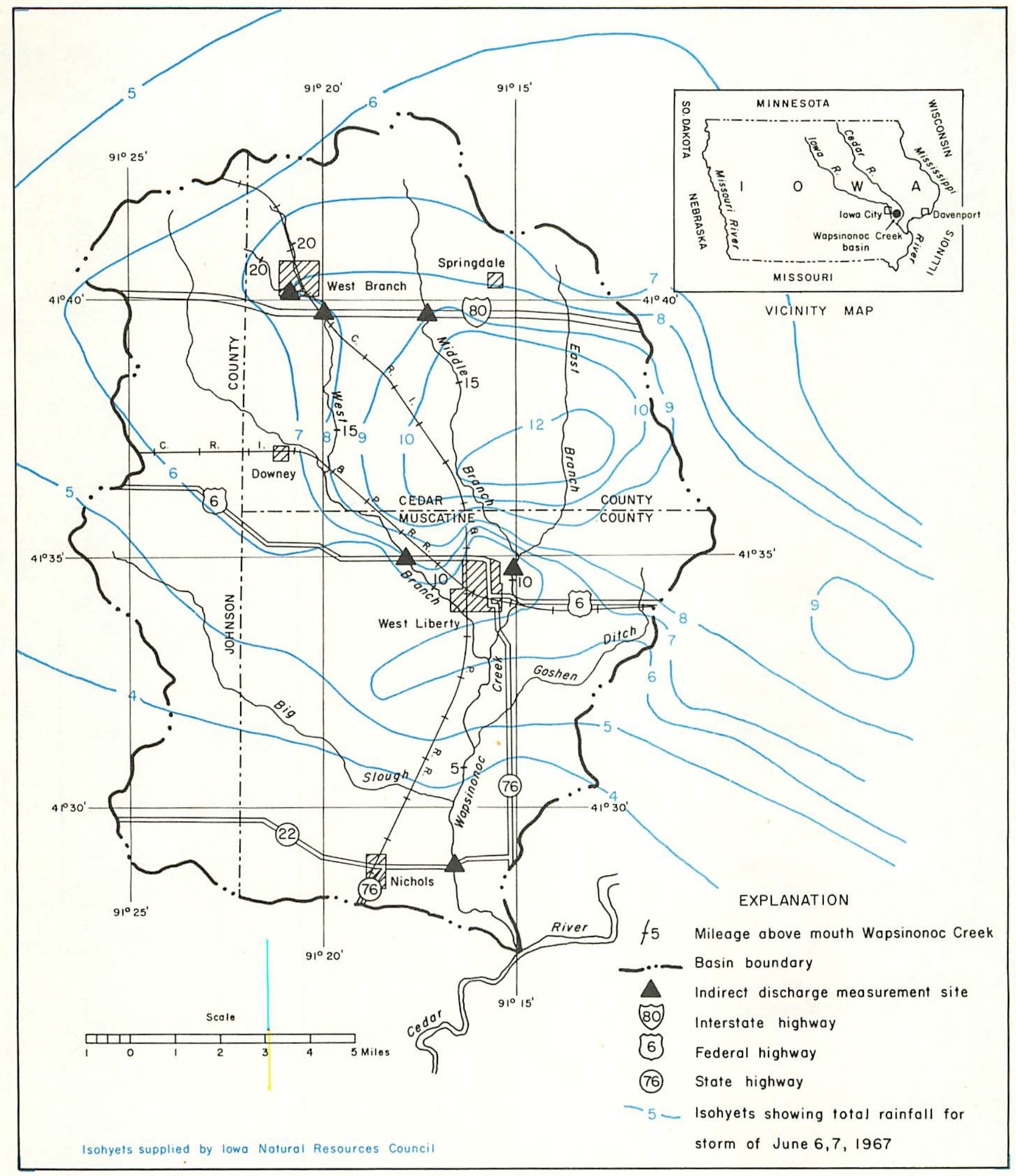

Figure I. Map of Wapsinonoc Creek basin showing indirect discharge measurement sites and isohyetal data. 
The basin is well served with a system of county roads, State and Federal highways, and railroads. County roads follow nearly all section lines. State highways 6,22 , and 76 serve the southern part of the basin; Interstate Highway $80(I-80)$ crosses the northern part of the basin in an east-west direction. The Chicago, Rock Island and Pacific Railroad (CRI\&P RR) has lines radiating in four directions from west Liberty. For the most part these lines are located in the valleys of the main stem and tributaries of the creek.

The various transportation systems have bridges which span the creek or its tributaries. The location of these crossings are tabulated later in the report.

\section{BASIC DATA}

Table 1 contains the data and allied information (except precipitation) collected or computed for the flood. Descriptions of the data are in the following paragraphs.

The normal annual precipitation for the basin is 33 inches (Schwob, 1966). There are no U.S. Weather Bureau rain gages within the basin so that the 1-sohyets on figure 1 are based upon measurements of rainfall caught in exposed containers and small unofficial gages maintained by residents. The reported maximum of 13 inches was measured by a fence-post gage at a point $3 \frac{1}{2}$ miles north and 2 miles east of West Liberty.

According to residents the rainfall occurred in two or more heavy showers. One account stated that 4.6 inches accumulated between 1930 and 2030 hours on June 6 in the area north of West Liberty and south of I-80 (fig. 1). A second intense burst of rainfall occurred from 0200 to 0500 hours on June 7, and a third substantial amount fell between 0800 and 1100 hours on the same day. This type of distribution is believed to have been 
basinwide and resulted in two or more peaks for the flood in the upperbasin reaches.

The U.S. Department of Commerce report on Climatological Data for Iowa for June 1967 shows little or no antecedent precipitation over the basin in the period June 1-5. Maximum amount reported in the east-central division of the state was 0.12 inch at Muscatine on June 5 .

Mileages shown in table 1 were determined from 1:24,000 scale topographic maps north of latitude $41^{\circ} 30^{\prime}$. South of this line they were obtained from aerial photographs. Mile 0 is at the mouth of Wapsinonoc Creek. The low-watci channels meander tortuously with many loops. For this reason a smooth curve through the estimated centroid of the wetted cross section of the valley was used to determine the mileage rather than the more common method of following the low-water channel.

Table 1 shows the mileage of tributaries, road crossings, and other points easily identified on figure 1 and provides a mileage reference system for that figure. Figure 2 is a graph of part of the data which appear in table 1 .

The drainage areas were determined from the 1:24,000 scale quadrangle maps for the upper basin. Soll maps and transportation maps were used for the areas not covered by quadrangle maps. Downstream from Highway 22 (mile 2.73) the drainage divide is not well defined and areas are approximate. Total area of the basin is about 180 square miles.

Flood elevations are shown for the upstream and downstream sides of bridges and for a few high-water marks between bridges. The landine 10cation in the table, shown as an index number (explained in footnotes to table 1), is for the downstream side of bridges. The streambed elevations shown are based upon the map contour crossings of the stream and determinations of bed elevations at indirect flow measurement sites. The elevations 
TABLE 1.--Data pertaining to flood of June 7, 1967, in Wapsinonoc Creek basin

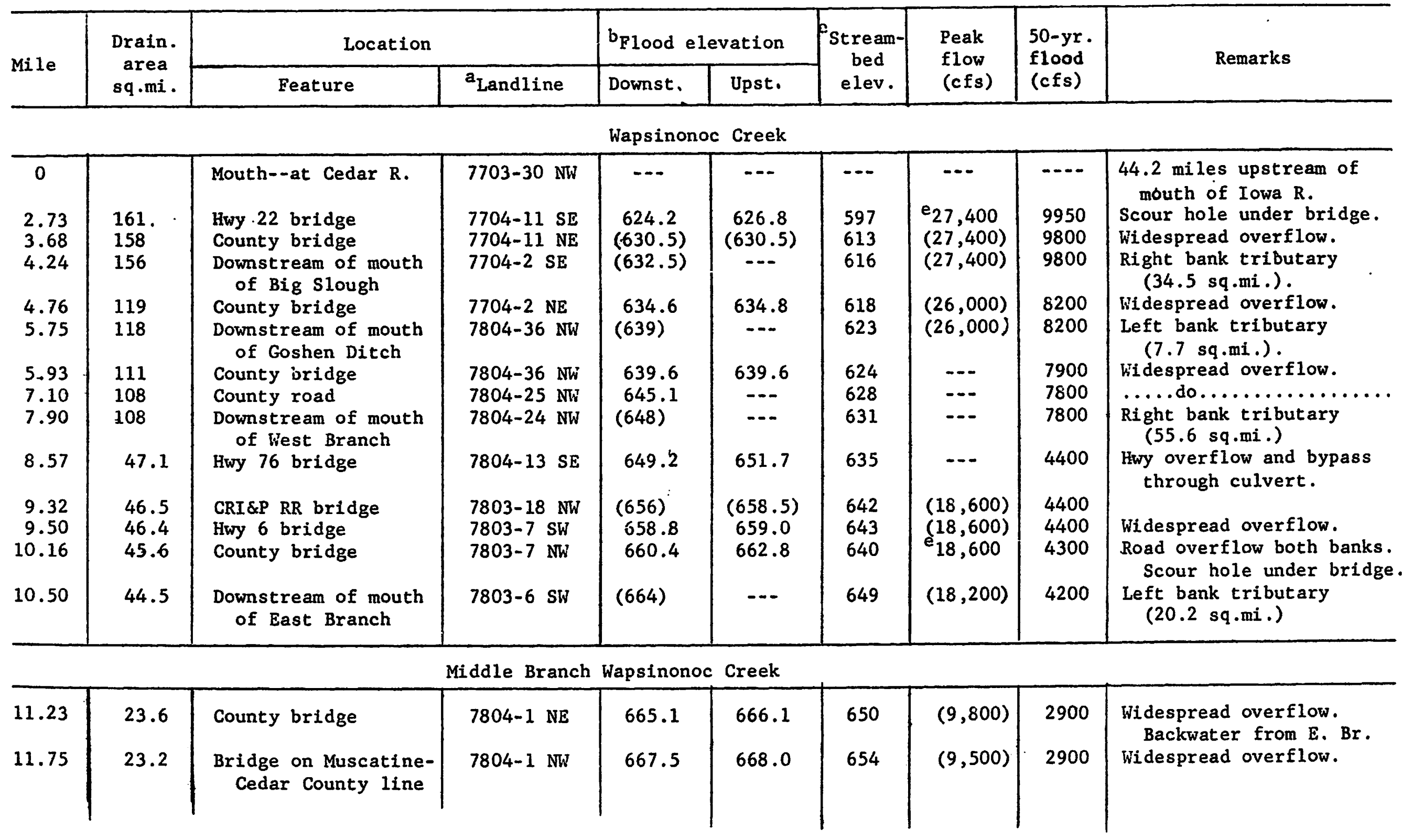


TABLE 1.--Data pertaining to flood of June 7, 1967, in Wapsinonoc Creek basin--Continued

\begin{tabular}{|c|c|c|c|c|c|c|c|c|c|}
\hline \multirow{2}{*}{ Mile } & \multirow{2}{*}{$\begin{array}{c}\text { Drain. } \\
\text { area } \\
\text { sq.mi. }\end{array}$} & \multicolumn{2}{|c|}{ Location } & \multicolumn{2}{|c|}{$\mathrm{b}_{\text {Flood Elevation }}$} & \multirow{2}{*}{$\begin{array}{c}\text { cstream- } \\
\text { bed } \\
\text { elev. }\end{array}$} & \multirow{2}{*}{$\begin{array}{l}\text { Peak } \\
\text { flow } \\
\text { (cfs) }\end{array}$} & \multirow{2}{*}{$\begin{array}{l}\mathrm{d}_{50-y r} \\
\text { flood } \\
\text { (cfs) }\end{array}$} & \multirow{2}{*}{ Remarks } \\
\hline & & Feature & $\mathrm{a}_{\text {Landline }}$ & Downst. & Upst. & & & & \\
\hline
\end{tabular}

Middle Branch Wapsinonoc Creek--Continued

\begin{tabular}{|c|c|c|c|c|c|c|c|c|c|}
\hline 12.34 & 21.3 & County bridge & $7904-36 \mathrm{SW}$ & 670.0 & 671.5 & 659 & $(8,800)$ & 2700 & Widespread overflow. \\
\hline 13.04 & 17.3 & $\ldots .$. do........... & $7904-35 \mathrm{NE}$ & 674.5 & 675.0 & 665 & $(7,100)$ & 2400 & $\ldots \ldots$ do $\ldots \ldots \ldots \ldots \ldots$ \\
\hline 14.04 & 16.5 & .....do... & $7904-26 \mathrm{NE}$ & 681.9 & 684.4 & 674 & $(6,800)$ & 2300 & $\ldots \ldots$ do $\ldots \ldots \ldots \ldots \ldots \ldots$ \\
\hline 15.06 & 15.0 & $\ldots \ldots$ do.......... & $7904-23 \mathrm{NE}$ & 690.8 & 693.3 & 682 & $(6,200)$ & 2200 & $\ldots \ldots$ do $\ldots \ldots \ldots \ldots \ldots \ldots$ \\
\hline 16.17 & 11.8 & $\ldots$. do........... & $7904-14 \mathrm{NW}$ & 698.8 & 700.7 & 691 & $(4,900)$ & 2000 & . do.. \\
\hline 16.45 & 11.6 & $\ldots$. do....... & 7904-15 NE & 701.3 & 703.0 & 693 & $(4,800)$ & 2000 & ..... do.. \\
\hline 16.57 & 10.7 & $\ldots \ldots$ do.......... & 7904-10 SE & 703.7 & 704.2 & 693 & $(4,600)$ & 1900 & ..... do. . \\
\hline 16.95 & 10.5 & Culvert under $I-80$ & $7904-11 \mathrm{SW}$ & 705.5 & 707.6 & 700 & $e_{4}, 380$ & 1800 & Minor hwy overflow. \\
\hline
\end{tabular}

West Branch Wapsinonoc Creek

\begin{tabular}{|c|c|c|c|c|c|c|c|c|c|}
\hline 7.90 & 108 & $\begin{array}{l}\text { Downstream of mouth } \\
\text { of West Branch }\end{array}$ & $7804-24 \mathrm{NW}$ & $(648)$ & $-\cdots$ & 632 & --- & 7800 & $\begin{array}{l}\text { Drain. area Wapsinonoc } \\
\text { Cr. upstream of } \mathrm{W} . \mathrm{Br} .- \\
52.0 \text { sq. mi. }\end{array}$ \\
\hline 8.85 & 54.7 & $\begin{array}{l}\text { County bridge--CRI\&P } \\
\text { RR bridge }\end{array}$ & $7804-13 \mathrm{SW}$ & 651.4 & 652.6 & 637 & $(21,000)$ & 5100 & Widespread overflow. \\
\hline 9.00 & -- & $\begin{array}{l}\text { High-water mark } \\
\text { right bank }\end{array}$ & $7804-13 \mathrm{NW}$ & 653.8 & --- & -- & --- & $-\cdots$ & \\
\hline 9.13 & 54.3 & County bridge & $7804-13 \mathrm{NW}$ & 653.9 & 654.0 & 638 & $(20,800)$ & 5000 & Widespread overflow. \\
\hline 9.63 & 54.1 & $\ldots$. do..... & 7804-14.NE & 656.2 & 657.0 & 640 & $(20,800)$ & 5000 & $\ldots \ldots$ do.............. \\
\hline 11.08 & 46.6 & Hwy 6 bridge & $7804-10 \mathrm{NE}$ & 661.8 & 663.0 & 646 & $\mathrm{e}_{18,000}$ & 4700 & 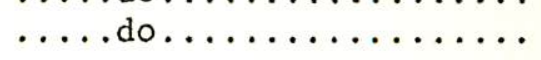 \\
\hline 12.20 & $\cdots$ & $\begin{array}{l}\text { High-water mark left } \\
\text { bank }\end{array}$ & $7804-4 \mathrm{NE}$ & 666.3 & -- & 656 & -. & $\ldots$ & \\
\hline 12.60 & -- & $\begin{array}{l}\text { Muscatine-Cedar } \\
\text { County line }\end{array}$ & 7804-4 NE & -- & -- & 658 & $\ldots$ & $\cdots$ & No bridge. \\
\hline 13.9 & 37.8 & $\begin{array}{l}\text { Downstream of right } \\
\text { bank tributary }\end{array}$ & 7904-32 NE & $(675)$ & $\ldots$ & 665 & $(15,100)$ & 4200 & $\begin{array}{l}\text { Right bank tributary } \\
(22.5 \text { sq.mi.). }\end{array}$ \\
\hline
\end{tabular}


TABLE 1.--Data pertaining to flood of June 7, 1967, in Waspinonoc Creek basin--Continued

\begin{tabular}{|c|c|c|c|c|c|c|c|c|c|}
\hline \multirow{2}{*}{ Mile } & \multirow{2}{*}{$\begin{array}{c}\text { Drain. } \\
\text { area } \\
\text { sq.mi. }\end{array}$} & \multicolumn{2}{|c|}{ Location } & \multicolumn{2}{|c|}{$\mathrm{b}_{\text {Flood Elevation }}$} & \multirow{2}{*}{$\mid \begin{array}{c}\text { cstream- } \\
\text { bed } \\
\text { elev. }\end{array}$} & \multirow{2}{*}{$\begin{array}{l}\text { Peak } \\
\text { flow } \\
\text { (cfs) }\end{array}$} & \multirow{2}{*}{$\begin{array}{r}\mathrm{d}_{50-y r} \\
\text { flood } \\
\text { (cfs) }\end{array}$} & \multirow[b]{2}{*}{ Remarks } \\
\hline & & Feature & ${ }^{\text {a Landline }}$ & Downst. & Upst. & & & & \\
\hline
\end{tabular}

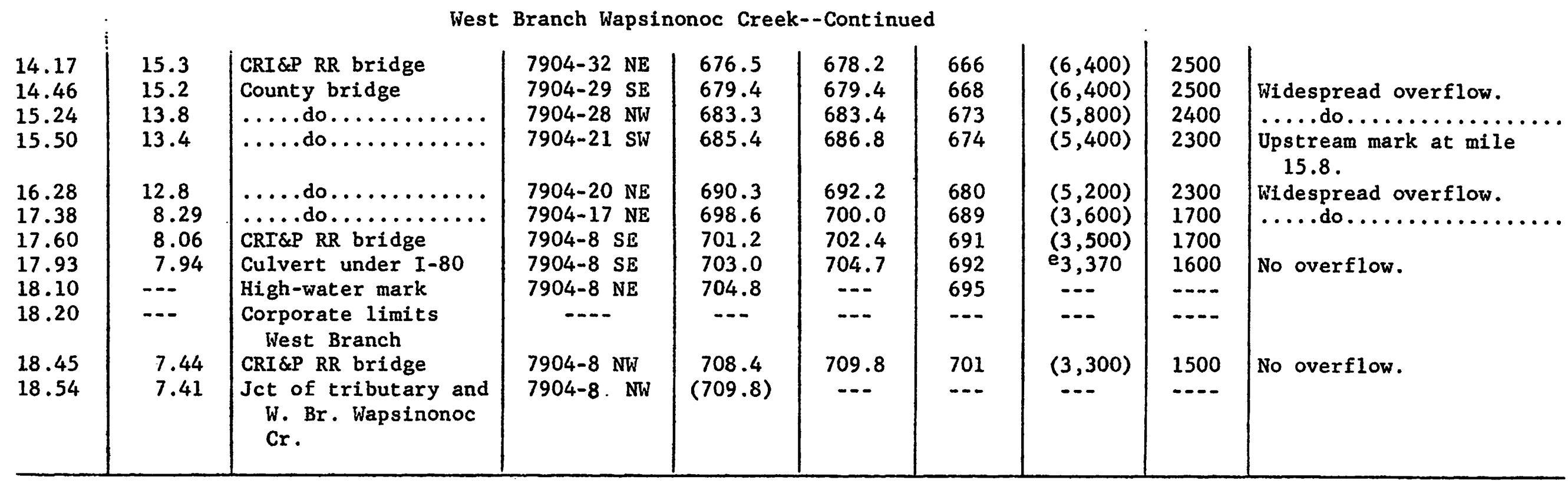

Tributary to West Branch Wapsinonoc Creek through Hoover Park

\begin{tabular}{|c|c|c|c|c|c|c|c|c|c|}
\hline 18.60 & 2.77 & $\begin{array}{l}\text { 2nd Street bridge } \\
\text { West Branch }\end{array}$ & 7904-8 NW & 710.2 & 710.2 & 703 & $(1,500)$ & 800 & Street overflowed. \\
\hline 18.72 & 2.73 & $\begin{array}{l}\text { Culvert under Downey } \\
\text { Street }\end{array}$ & 7904-8 NW & 711.4 & 713.8 & 704 & $e_{1,500}$ & 800 & .....do...... \\
\hline 18.95 & $-\cdots$ & $\begin{array}{l}\text { West boundary Hoover } \\
\text { Park }\end{array}$ & 7904-9 NE & 715.9 & $\cdots$ & 708 & ... &.-- & \\
\hline
\end{tabular}


TABLE 1.--Data pertaining to flood of June 7, 1967, in Wapsinonoc Creek basin--Continued

\section{NOTES}

Figures in parentheses pertaining to elevation or discharge are estimates from relations developed from known data.

a. Landline locations are shown as an index number; for example, mile 0 is in the NWh sec.30, T.77 N., R.3 W., the index number is $7703-30 \mathrm{NW}$.

b. In feet above mean sea level, 1929 General Adjustment.

c. In feet above mean sea level, 1929 General Adjustment from profile developed from 1:24,000 quadrangle maps and surveyed data.

d. Peak discharge in cfs.

e. Results of indirect discharge measurement. 


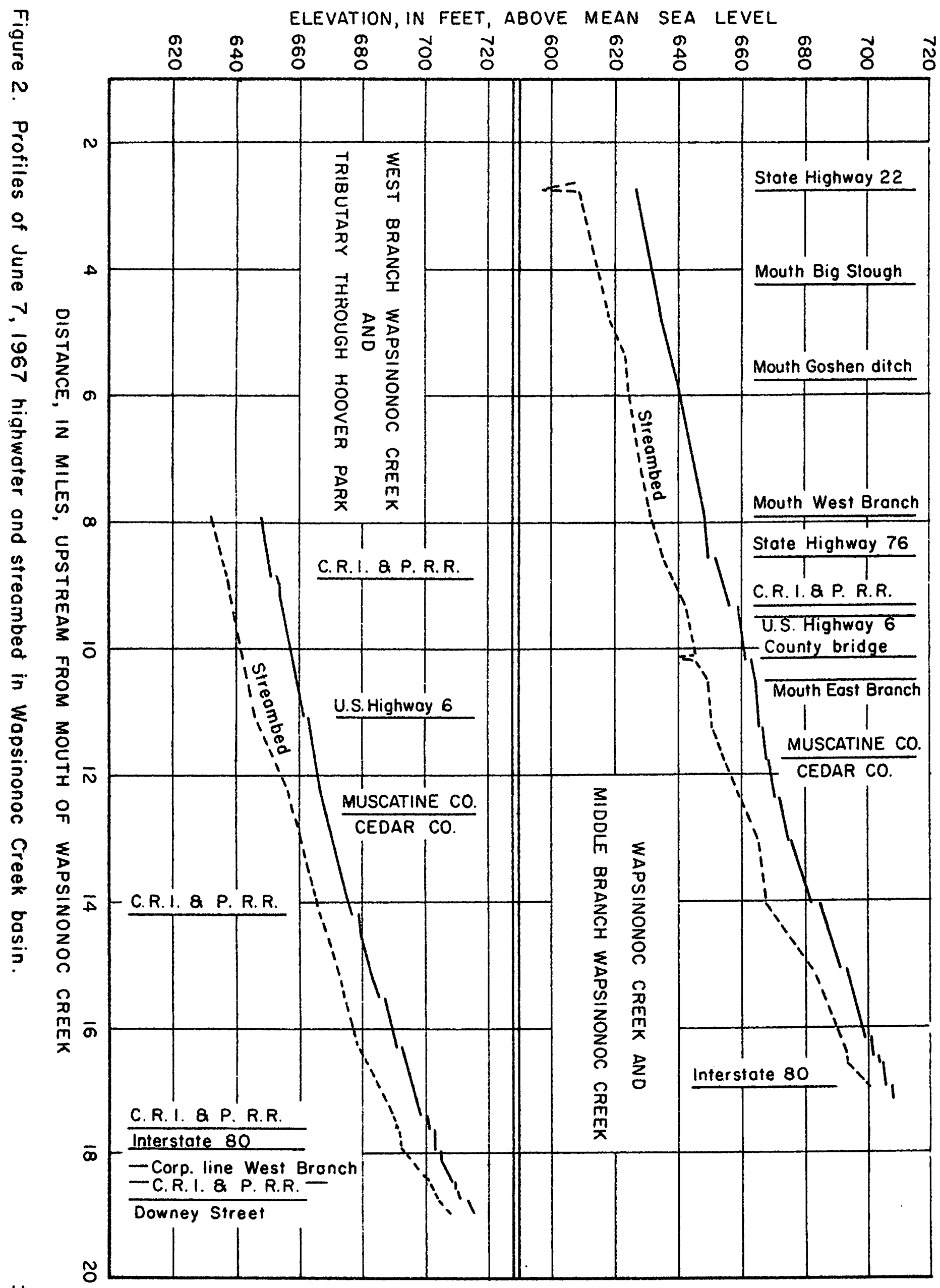


and distances can be used to prepare flood elevation and streambed profiles at a scale larger than that of figure 2 .

The peak discharge in cubic feet per second (cfs) is shown at a number of locations in the basin. At locations where indirect measurements were made the discharge is that computed for the measurement. At other 10cations parenthetical figures indicate estimates based upon drainage areas and the results of the indirect measurements.

The dischage for the 50-year recurrence interval flood has been computed and shown in table 1. The method of computation of this discharge has been published (Schwob, 1966). This method used drainage area,. stream slope, and normal annual precipitation as parameters in a formula, determined by a multiple regression, to compute the mean annual flood. This in turn is multiplied by a defined factor to compute the 50-year flood.

\section{EFFECT OF THE FLOOD}

Property losses were minor and there was no known loss of human life or injury due to the flood.

The town of West Branch on the West Branch of the Creek was the community most affected by the flood. The stream branches near the southeast corner of the town. The larger tributary flows from the north along the east edge of the business district; the smaller tributary flows from the west through Hoover Park in the southwest part of town. Several business places in the town were damaged by floodwaters on the first floor level. Hoover Park sustained damages to the custodian's home (basement and contents flooded) and inundation of the floor of several storage and work buildings. The Hoover birthplace cottage and library were not flooded. A small amount of damage was incurred elsewhere in the park to a footbridge 
over the low-water channel and from mud and debris deposited on the flooded area and in the decorative plantings. The monetary value of the damage in the West Branch area was not determined.

West Liberty was affected to some extent by flooding from the main creek and from the West Branch of the creek. Several barns near the east side of town were flooded (by Wapsinonoc Creek). Three houses were threatened at the southwest corner of town (by West Branch Wapsinonoc Creek) and two were saved from damage by hastily installed plastic sheeting over doors and windows.

The effect on county roads and highways was generally limited to brief periods of traffic interruption by overflow. One small county bridge in the downstream part of the basin was washed out. Highways and roads were universally overflowed at the peak of the flood and West Liberty was virtually isolated by floodwaters for a short time. Interstate Highway 80 was overflowed (by the Middle Branch Wapsinonoc Creek) near the community of Springdale. However, there was no damage to the highway and no known interruption of traffic. South of West Liberty the low relief and the Highway 76 fill permitted floodwater to flow south in a reach upstream (east) of the Highway. This water eventually returned to the Creek at some distance downstream through culverts under the highway, principally those for Goshen Ditch.

Agricultural damage is believed to have been slight. Some fences were partly destroyed and a few basements and outbuildings at farmsteads were reported flooded. Crops in general were in the early stages of growth and were not greatly damaged by the brief period of inundation. Some livestock were said to have been drowned but the numbers and value were not reported. 


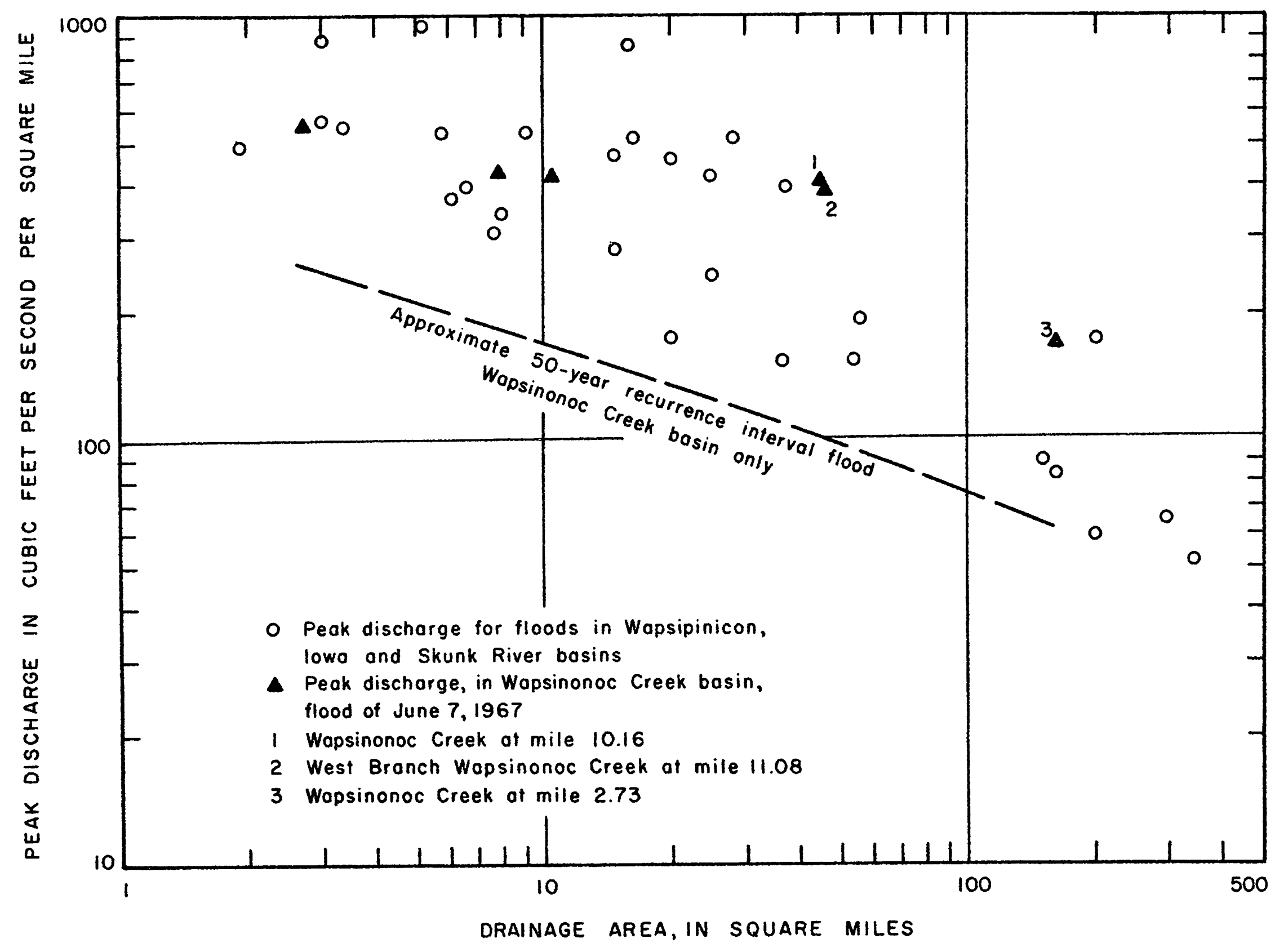

Figure 3. Peak discharge of Wapsinonoc Creek and selected streams. 


\section{DISCUSSION}

Figure 3 shows the relation between the Wapsinonoc Creek crest discharges (at measuring points) and the approximate 50-year recurrence interval flood. It also shows the highest recorded peaks for the past 50 years on nearby streams. The peaks on the Wapsinonoc Creek and one of its major tributaries (numbers 1-3 on fig. 3) are among the greatest observed during the period. The location of the storm over a rural rather than an urban area minimized the loss of life and damage.

\section{REFERENCE}

Schwob, H.H., 1966, Magnitude and frequency of Iowa Floods: Iowa Highway Research Board, Bull. 28, pt. 1, 47 p. 


\section{APPENDIX}

\section{Bench-mark data}

The temporary bench marks listed on the following pages were established during leveling to determine flood elevations. Bench marks were set at all bridges and at several intermediate points.

Level lines were run from first- or second-order bench marks established and adjusted by the U.S. Coast and Geodetic Survey or the Topograhic Division, U.S. Geological Survey, and referenced to mean sea level datum, 1929 general adjustment. The elevations shown herein are of third-order accuracy .

Each bench mark is identified by an index number and letter combination which is composed of the Congressional township, range, section number, and the quarter-section in which it is located. The township and range numbers have been combined into a four-digit number, such as 7904 for Township 79 North, Range 4 West. This is followed by a dash and the section number in which the mark is located. Within the section, the quarter in which the mark is located is designated by $N E, . . S E$, NW, SW. A number in parentheses following this letter designation indicates the numbrical order of the marks in that particular quarter. Thus, the first mark located in the Northeast quarter of Section 26, Township 79 North, Range 4 West would be designated 7904-26 NE (1). The index number serves to describe the landline location of the mark without further reference in the body of the description. The name of the county in which the mark is located, in parentheses, follows the index number.

7703-6-SW (1) (Muscatine) - About 5 miles south of West Liberty, Iowa, along Highway 76 at county road intersection; 32 feet north and 75 feet west of intersection; 1 foot south of fence line and 2 feet west of power pole; concrete post with standard tablet marked "632 19 LMT 1963." Elev. 631.785 
7703-7 SW (1) (Muscatine) - About 6 miles south of West Liberty, Iowa, along Highway 76 to junction with Highway 22; on east side of intersection in power pole; pole spike and collar. Elev. 628.75

7704-1 SE (1) (Muscatine) - About 5 miles south of West Liberty, Iowa, along Highway 76 and $1 / 2$ mile west of highway; 180 feet east of J.K. Meyers' farm drive in power pole at "T" fence north; RR spike--pole painted "U.E. 635.3." Elev. 635.34

7704-2 (1) (Muscatine) - About 5 miles south of West Liberty, Iowa, along Highway 76 and $1-1 / 2$ miles west along gravel road; 100 feet landward of left upstream corner of Wapsinonoc Creek bridge; on power pole painted "BM"; pole spike and collar. Elev. 624.26

7704-11 SE (1) (Muscatine) - About 1-3/4 miles east of Nichols, Iowa, at the Highway 22 bridge over Wapsinonoc Creek; on the left upstream wingwall; chiseled cross (found) painted. Elev. 628.14

7803-7 SW (1) (Muscatine) - At West Liberty at east edge of town on Highway 6 bridge over Wapsinonoc Creek; on left downstream wingwall; chiseled cross. Elev. 656.97

7803-7 NW (1) (Muscatine) - Near the northeast corner of West Liberty at county bridge over Wapsinonoc Creek; on downstream right handrail abutment on southeast corner of top; chiseled square. Elev. 665.86

7804-1 NE (1) (Muscatine) - About 1 mile north of West Liberty, Iowa, at county road " $S$ " bridge over the Middle Branch Wapsinonoc Creek; on top of upstream left abutment; Monel metal rivet (found). Elev. 665.13

7804-4 NE (2) (Muscatine) - About 2 miles east and 1 mile south of Downey, Iowa, near curve in county road; under CRI\&P RR; on left upstream corner of culvert (not marked). Elev. 665.28

7804-10 NE (1) (Muscatine) - About 1-3/4 miles northwest of West Liberty, Iowa, at Highway 6 bridge over the West Branch Wapsinonoc Creek; at left downstream corner of bridge on top of curb; chiseled square. Elev. 666.26

7804-11 NW (1) (Muscatine) - About 1-1/4 miles northwest of West Liberty, Iowa, along the CRI\&P RR at Highway 6 overpass bridge; on top of southwest wingwall; chiseled square. Elev. 705.61

7804-12 SE (1) (Muscatine) - In south part of West Liberty, Iowa, at CRI\&P $\mathrm{RR}$ and Highway/76 intersection; on south side of track, 20 feet east of crossing on northwest corner of control box footing; chiseled square. Elev. 675.57

7804-12 SW (1) (Muscatine) - At West Liberty, Iowa, at the CRI\&P RR station at the northwest corner of the ticket office; 16 inches northwest of window and 4 feet above platform; standard tablet stamped "B 77 1934" set in vertical wall. Elev. 674.694 
7804-13 SE (1) (Muscatine) - About 1 mile south of West Liberty at the Highway 76 bridge over Wapsinonoc Creek; on top of left downstream wingwall; chiseled square. Elev. 655.79

7804-13 SW (1) (Muscatine) - About $3 / 4$ mile southwest of West Liberty, Iowa, along the CRI\&P RR at road crossing; in southwest quadrant of crossing on top of corner fence post; painted nail. Elev. 650.67

7804-14 NE (1) (Muscatine) - About $1 / 2 \mathrm{mile}$ southwest of West Liberty at county bridge over West Branch Wapsinonoc Creek; at right upstream corner in top of piling; chiseled cross on bolt painted red. Elev. 655.51

7804-14 NE (4) (Muscatine) - At west edge of West Liberty, Iowa, at bridge over West Branch Wapsinonoc Creek; on top of right downstream wingwall; chiseled square. Blev. 656.44

7804-23 SE (1) (Muscatine) - About 2.2 miles southwest of West Liberty, Iowa, along CRI\&P RR at a county road crossing; in northwest quadrant of crossing on west end of round::steel culvert pipe; chiseled cross painted red. Elev. 644.63

7804-24 NW (1) (Muscatine) - About 1.3 miles southwest of West Liberty, Iowa, along CRI\&P RR; on 20-foot RR bridge no. 601 in top of west end of north stone abutment; 10 feet west of center of track; standard tablet marked "C 77 1934." Elev. 649.910

7804-25 SE (1) (Muscatine) - About 3-1/2 miles south of West Liberty, Iowa, along Highway 76 at intersection with county road; in northwest quadrant of intersection in corner fence post; RR spike in post (found). Elev. 651.92

7804-25 SE (2) (Muscatine) - About 3 miles south of West Liberty, Iowa, along Highway 76 at bridge over Goshen Ditch; at right downstream corner of bridge on top of concrete guardrail; chiseled square painted red. Elev. 649.03

7804-25 SW (1) (Muscatine) - About 3 miles south of West Liberty, Iowa, along Highway 76 and 1 mile west on gravel road at bridge over Wapsinonoc Creek; on right upstream bridge seat; bolt painted red. Elev. 636.25

7804-26 SW (1) (Muscatine) - About 3.4 miles southwest of West Liberty, Iowa, along the CRI\&P RR at road crossing; 20 feet northwest of crossing on top southwest end of headwall of $1^{\prime} \times 1^{\prime}$ concrete box culvert; standard tablet stamped "D 77 1934." Elev. 647.102

7804-35 SE (1) (Muscatine) - About 4 miles south of West Liberty along Highway 76 and $1-1 / 2$ miles west on gravel road; in northeast quadrant of road intersection in power pole marked "BM"; pole spike and collar. Elev. 636.38

7804-35 SE (2) (Muscatine) - About $4 \mathrm{mil}$ les south of West Liberty, Iowa, along Highway 76 and 1 mile west along gravel road; at bridge over Wapsinonoc Creek on left upstream bridge seat; red painted bolt. Elev. 630.06 
7904-3 SE (1) (Cedar) - About $3 \mathrm{miles}$ east of West Branch, Iowa, on former Highway 1 at bridge over Middle Branch Wapsinonoc Creek; at left upstream corner of bridge on top of curb; Iowa Highray Commission bench mark plug. Elev. 719.38

7904-6 SW (1) (Cedar) - Near west stde of West Branch, Iowa, at bridge on former Highway 1 over tributary to West Branch Wapsinonoc Creek; in first telephone pole upstream and right of concrete bridge; nail in painted mark. Elev. 720.93

7904-7 NE (2) (Cedar) - At West Branch, Iowa, in west end of Hoover Park at fence corner near the center of the north portion of the loop drive; about 350 feet southwest of upstream foot bridge; in corner post 5 inches above the ground; scaffold nail driven through round tin. Elev. 715.10

7904-8 NE (1) (Cedar) - About 1/2 mile southeast of West Branch, Iowa, at triple $12^{\prime} \times 12^{\prime}$ concrete box culvert under Interstate Highway 80 ; on top of center of upstream headwall; chiseled cross (found). Elev. 706.27

7904-8 SE (1) (Cedar) - About $3 / 4$ mile southeast of West Branch, Iowa, along the CRI\&P RR at bridge over West Branch Wapsinonoc Creek; on right upstream abutment; chiseled square. Elev. 703.79

7904-8 NW (1) (Cedar) - At West Branch, Iowa, on the CRI\&P RR bridge in the southeast part of town; in the top of the upstream end of the left abutment; standard tablet stamped "V 76 1934." Elev. 709.670

7904-11 SW (1) (Cedar) - About $3 \mathrm{miles}$ east and 3/4 mile south of West Branch, Iowa, at north-south bridge over Middle Branch Wapsinonoc Creek; at left upstream corner of bridge; cross on red painted bolt. Elev. 704.48

7904-11 NW (1) (Cedar) - About 3 miles east of West Branch, Iowa, at triple barreled concrete box culvert under Interstate Highway 80 ; on top and center of upstream headwall; Iowa Highway Commission bench mark plug. Elev. 709.85

7904-14 NW (1) (Cedar) - About 3 miles east and 1-1/4 miles south of West Branch, Iowa, at bridge over Middle Branch Wapsinonoc Creek on northsouth road; at left upstream corner of bridge; chiseled square painted red. Elev. 703.17

7904-15 NE (2) (Cedar) - About 3 miles east and 1 mile south of West Branch, Iowa, at east-west county bridge over Middle Branch Wapsinonoc Creek; on right downstream wingwal1; horizontal bolt painted red. Elev. 702.63

7904-17 NE (1) (Cedar) - About $1 \mathrm{mile}$ south and $3 / 4$ mile east of West Branch, Iowa, at bridge over West Branch Wapsinonoc Creek; at left downstream corner of bridge on abutment; chiseled square. Elev. 701.88 
7904-20 NE (1) (Cedar) - About 2 miles south ind 1 mile east of West Branch, Iowa, at bridge over West Branch Wapsinonoc Creek; at second guardrail post from right downstream corner of bridge; bolt painted red. Elev. 693.59

7904-20 SE (1) (Cedar) - About 2-1/2 miles south and 1 miles east of West Branch, Iowa; in 5th power pole north of West Branch Wapsinonoc Creek bridge; 1 pole south of farm drive at field entrance; nail in pole. Elev. 686.50

7904-21 SW (1) (Cedar) - About 3 miles southeast of West Branch, Iowa, at bridge over West Branch Wapsinonoc Creek; in center of concrete bridge floor; chiseled square (found). Elev. 687.25

7904-23 NE (1) (Cedar). - About 1.8 miles east of Centerdale at bridge over Middle Branch Wapsinonoc Creek; at right downstream corner of bridge on bridge seat; chiseled cross. Elev. 691.56

7904-23 SE (1) (Cedar) - About 1-1/2 miles southeast of Centerdale at bridge on east-west road over Middle Branch Wapsinonoc Creek; in center of concrete deck; chiseled square marked "UE 686.4" (found). Elev. 686.37

7904-26 NE (1) (Cedar) - About 1-1/2 miles southeast of Centerdale at bridge over Middle Branch Wapsinonoc Creek on east-west road; at left downstream corner of bridge; chiseled cross on rivet painted red. Elev. 685.72

7904-28 NW (1) (Cedar) - About 3 miles southeast of West Branch, Iowa, in southeast quadrant of " $T$ " road intersection; 100 feet south and 33 feet east of intersection; between telephone pole and fence; concrete post with standard tablet stamped "694 4 LMT 1963." Elev. 693.831

7904-29:SE;(1);(Cedar) - About 3/4 mile east of Downey, Iowa, on bridge over tributary of West Branch Wapsinonoc Creek; 25 feet west of right downstream corner of bridge in telephone pole; paint and nall. Elev. 678.67

7904-29 SE (3) (Cedar) - About 3/4 mile east of Downey, Iowa, at county bridge over tributary of West Branch Wapsinonoc Creek on left downstream abutment; chiseled square. Elev. 675.55

7904-29 SE (4) (Cedar) - About 3/4 miles east of Downey, Iowa, on CRI\&P RR bridge over Tributary of West Branch Wapsinonoc Creek; on right downstream abutment; chiseled square. Elev. 679.73

7904-32 NE (1) (Cedar) - About 7/8 mile southeast of Downey, Iowa, on the CRI\&P RR bridge over the West Branch Wapsinonoc Creek; on right downstream abutment; chiseled square. Elev. 680.14

7904-33 SE (1) (Cedar) - About 1-1/2 miles east and 1/2 mile south of Downey, Iowa, on south side of CRI\&P RR: two telegraph poles east of bridge over RR; top of bolt head in bottom wire clamp on east side of stub supported pole. Elev. 690.40 
7904-35 NE (1) (Cedar) - About 3 miles northwest of West Liberty, Iowa, at bridge over Middle Branch Wapsinonoc Creek on east-west road; at right downstream corner of bridge; chiseled cross on rivet painted red.

Elev. 674.39

7904-35 SE (1) (Cedar) - About 1-3/4 miles northwest of West Liberty, Iowa, along CRI\&P RR to road crossing; 45 feet northeast of center line of track; 35 feet northwest of center line of road; 5 feet southwest of fence line; standard tablet stamped "Z 76 1934." Elev. 700.530

7904-36 SW (1) (Cedar) - About 1-3/4 miles north of West Liberty, Iowa, at bridge over Middle Branch Wapsinonoc Creek; in left upstream abutment; head of horizontal bolt painted red. Elev. 664.24

7904-36 NW (1) (Cedar) - About 2 miles north and $1 / 2 \mathrm{mile}$ west of West Liberty, Iowa, at county bridge on north-south road over Middle Branch Wapsinonoc Creek; on landward side of left downstream nbutnent; borizontal bolt painted red. Elev. 671.00 
